\title{
Seasonal and latitudinal variation in seagrass mechanical traits across Europe: The influence of local nutrient status and morphometric plasticity
}

L. M. Soissons $\mathbb{B D}^{1 *}{ }^{1 *}$ M. M. van Katwijk, ${ }^{2}$ G. Peralta ${ }^{(D,}{ }^{3}$ F. G. Brun, ${ }^{3}$ P. G. Cardoso, ${ }^{4}$ T. F. Grilo, ${ }^{5}$ B. Ondiviela, ${ }^{6}$ M. Recio, ${ }^{6}$ M. Valle, ${ }^{7,8}$ J. M. Garmendia, ${ }^{7}$ F. Ganthy, ${ }^{9}$ I. Auby, ${ }^{9}$ L. Rigouin, ${ }^{9}$ L. Godet, ${ }^{10}$ J. Fournier, ${ }^{11}$ N. Desroy, ${ }^{12}$ L. Barillé, ${ }^{13}$ P. Kadel, ${ }^{14}$ R. Asmus, ${ }^{14}$ P. M. J. Herman, ${ }^{1,2, a}$ T. J. Bouma ${ }^{1}$ ${ }^{1}$ NIOZ Royal Netherlands Institute for Sea Research, Department of Estuarine and Delta Systems (EDS), and Utrecht University, Yerseke, The Netherlands

${ }^{2}$ Institute for Wetland and Water Research, Department of Environmental Science, Radboud University, Nijmegen, The Netherlands

${ }^{3}$ Departamento de Biología, Área de Ecología, Facultad de Ciencias del Mar y Ambientales, Universidad de Cádiz, Puerto Real, Cádiz, Spain

${ }^{4}$ CIMAR - Interdisciplinary Centre of Marine and Environmental Research, Matosinhos, Portugal

${ }^{5}$ MARE - Marine and Environmental Sciences Centre, Laboratório Marítimo da Guia, Faculdade de Ciências da Universidade de Lisboa, Cascais, Portugal

${ }^{6}$ Environmental Hydraulics Institute "IH Cantabria", Universidad de Cantabria, Santander, Spain

${ }^{7}$ AZTI, Marine Research Division, Pasaia, Spain

${ }^{8}$ Universidad Laica Eloy Alfaro de Manabí, Facultad de Ciencias del Mar, Ciudadela Universitaria, Manta, Ecuador

${ }^{9}$ IFREMER - LER/AR, Arcachon, France

${ }^{10}$ CNRS, UMR 6554 LETG-Nantes Géolittomer, Université de Nantes, Nantes Cedex 3, France

${ }^{11}$ CNRS, UMR 7208 BOREA, Station de Biologie Marine MNHN, Concarneau Cedex, France

${ }^{12}$ IFREMER - Laboratoire Environnement et Ressources, Station de Dinard, Dinard, France

${ }^{13}$ Université de Nantes, Equipe Mer-Molécules-Santé EA 2160, Faculté des Sciences et des Techniques, Nantes Cedex 3, France

${ }^{14}$ Alfred-Wegener-Institut Helmholtz-Zentrum für Polar- und Meeresforschung, Wadden Sea Station Sylt, List, Germany

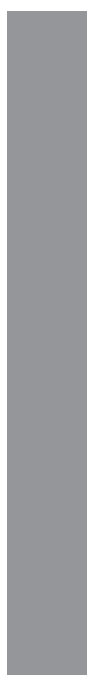

\begin{abstract}
Seagrasses are marine flowering plants distributed worldwide. They are however threatened, mostly due to the increase of human activities. Seagrasses have the capacity to adapt their morphological, physiological, and mechanical traits to their local conditions. Mechanical traits have been identified as a good tool to investigate a plant-species capacity to withstand physical forces or disturbances but are still sparsely studied in seagrasses. With this study, we aimed to assess how the mechanical traits of a broadly spread seagrass species vary along a latitudinal gradient in relation to its morphometric plasticity and nutrient status. We found that seagrasses acclimate their mechanical traits in relation to their physiological or morphological traits, both over the growing season and across a latitudinal range: leaves were weaker and thinner in northern areas, particularly at the end of the growing season. Besides the influence of the latitudinal gradient, leaf mechanical strength and stiffness were both strongly affected by their morphometric plasticity. Moreover, we showed that leaves mechanical traits change depending on their nutrient status: leaves were stronger and stiffer in oligotrophic conditions as compared to more eutrophic conditions. Thus, our results imply that, under eutrophication, leaves become weaker and thus more vulnerable to physical forces. This vulnerability is higher in the north at the end of the growing season. The latter is consistent with the more ephemeral character of northern seagrass meadows, in contrast to the more evergreen southern meadows.
\end{abstract}

*Correspondence: laura.soissons@nioz.nl

apresent address: Deltares, Delft, The Netherlands

Additional Supporting Information may be found in the online version of this article.
Seagrasses are marine flowering plants widely distributed worldwide (Short et al. 2007), providing highly valuable ecosystem services for coastal areas (Orth et al. 2006). Their development and distribution depend on various conditions such as light and nutrient availability (Duarte 1991; Grice et al. 1996; Wicks et al. 2009), hydrodynamic conditions (varies per species), and sediment characteristics (Koch 2001; 
de Boer 2007; Eriksson et al. 2010). Seagrass meadows are facing severe declines worldwide, due to the increase of human activities (Orth et al. 2006; Halpern et al. 2008; Waycott et al. 2009), threatening their resilience and survival. Being sessile organisms, seagrasses can to some extent adapt their morphological and physiological traits to their local conditions, influencing their resilience to (natural or human-induced) stressors (Short and Wyllie-Echeverria 1996; Touchette and Burkholder 2000; Peralta et al. 2005; Lee et al. 2007; Cabaço et al. 2009; de los Santos et al. 2010, 2013).

There are several known examples where seagrass have acclimatized their morphological traits to abiotic conditions. When light is limiting, seagrasses have been shown to reduce their investment in below-ground biomass to maintain their photosynthetic production (Peralta et al. 2002; Lee et al. 2007; de los Santos et al. 2010). In contrast, in highly dynamic environments with no limiting light, seagrasses can adapt their morphology by allocating more energy to their below-ground structures (Peralta et al. 2005). Seagrasses are also capable of changing their physiological traits in response to abiotic conditions. For example, their leaf C : Nratio decreases under eutrophication (Duarte 1990; Roca et al. 2016). Besides modifying only their morphological or physiological traits, seagrasses can also modify their mechanical traits such as leaf strength or stiffness in response to external forcing (de los Santos et al. 2013).

Mechanical traits have been identified as a good tool to investigate a plant-species capacity to withstand physical forces or disturbances (Onoda et al. 2011; Puijalon et al. 2011; de los Santos et al. 2013). They are evaluated by measuring the strength, stiffness, or extensibility of tissues before breakage and have been the focus of several studies on freshwater (Puijalon et al. 2011), terrestrial plants (Onoda et al. 2008, 2011) as well as marine macroalgae (Harder et al. 2006; Demes et al. 2013). However, for seagrass species, there are still only a very limited number of studies available on mechanical traits/strength of leaves and reproductive shoots (Patterson et al. 2001). Available studies have focused on comparing species-specific traits (de los Santos et al. 2016) and on quantifying the effect of specific abiotic conditions such as the effect of nutrient enrichment (La Nafie et al. 2012, 2013), wave exposure (de los Santos et al. 2010; La Nafie et al. 2012), and the spatial and temporal variability in abiotic conditions (de los Santos et al. 2013). In their study, La Nafie et al. (2013) demonstrated that nutrient enrichment significantly reduced leaves strength and stiffness in Halophila ovalis. These changes were related to the induced increase in leaves dimensions following abiotic changes (nutrient enrichment or shading). This relationship between leaves dimensions (leaf width) and mechanical traits was confirmed by de los Santos et al. (2016). Such changes in leaves dimensions and mechanical traits related to changes in abiotic conditions could lead to disparities in seagrass response to stressors. Understanding how stressors may affect seagrass properties on a larger geographic scale, such as across a latitudinal gradient and over the growing season, has not been resolved, despite the importance for understanding seagrass resilience to global warming in combination with other human induced stressors (Short and Neckles 1999; Duarte 2014).

In this study, we aimed to assess how the mechanical traits of a broadly spread seagrass species vary along a latitudinal gradient. Using Zostera noltei as a model species, we focused our study on two critical moments in their growing season: the peak of growth, when their productivity and biomass reaches a maximum; and at the end of growing season, when the biomass decreases before the winter period. We hypothesize that (1) leaves mechanical traits will vary along a latitudinal gradient, as well as (2) other the growing season; and that (3) the nutrient status of a seagrass meadow lead to altered mechanical properties, as found in tropical species (La Nafie et al. 2013). That is, for the same species, we expect plants at oligotrophic locations to be mechanically stronger than those at eutrophic locations. We furthermore hypothesize that (4) changes in mechanical traits along the latitudinal gradient are mainly due to morphometric plasticity, as a recent study demonstrated that leaf width was the most important factor affecting leaf strength across species (de los Santos et al. 2016).

\section{Material and methods}

\section{Study area and experimental design}

$Z$. noltei meadows can be found in intertidal areas along the European coastline (Valle et al. 2014). To evaluate the large-scale spatial and seasonal variation of seagrass mechanical traits, 12 well studied $Z$. noltei meadows were selected and sampled at two different time periods corresponding to the peak and the end of the seagrass growing season (i.e., based on local expertise). Meadows were selected according to four main criteria: (1) healthy seagrass meadow; (2) with a minimum $30 \times 30 \mathrm{~m}$ homogeneous surface area; (3) located in an intertidal area; and (4) with a sampling area located in the middle of the meadow and not at the edge. The selected meadows followed a latitudinal gradient from South to North, being: 1. Cadiz (Spain); 2 and 3. Mondego estuary (Portugal); 4. Santander (Spain); 5. Bidasoa estuary (France); 6 and 7. Arcachon Bay (France); 8. Noirmoutier (France); 9. St-Jacut-de-la-mer (France); $10 \& 11$. The Oosterschelde (Netherlands); and 12. Sylt (Germany) (Fig. 1; Table 1). For some meadows, two close sites were selected in order to account for local variability and to compare sites according to their health status (i.e., Mondego estuary sites 2. Upstream and 3. Downstream), their elevation (i.e., Arcachon Bay sites 6. Germanan and 7. Hautebelle) and their exposure to hydrodynamics (i.e., Oosterschelde sites 10. Oostdijk and 11. Dortsman) (see Fig. 1, Table 1, and Supporting Information for background information on all selected 


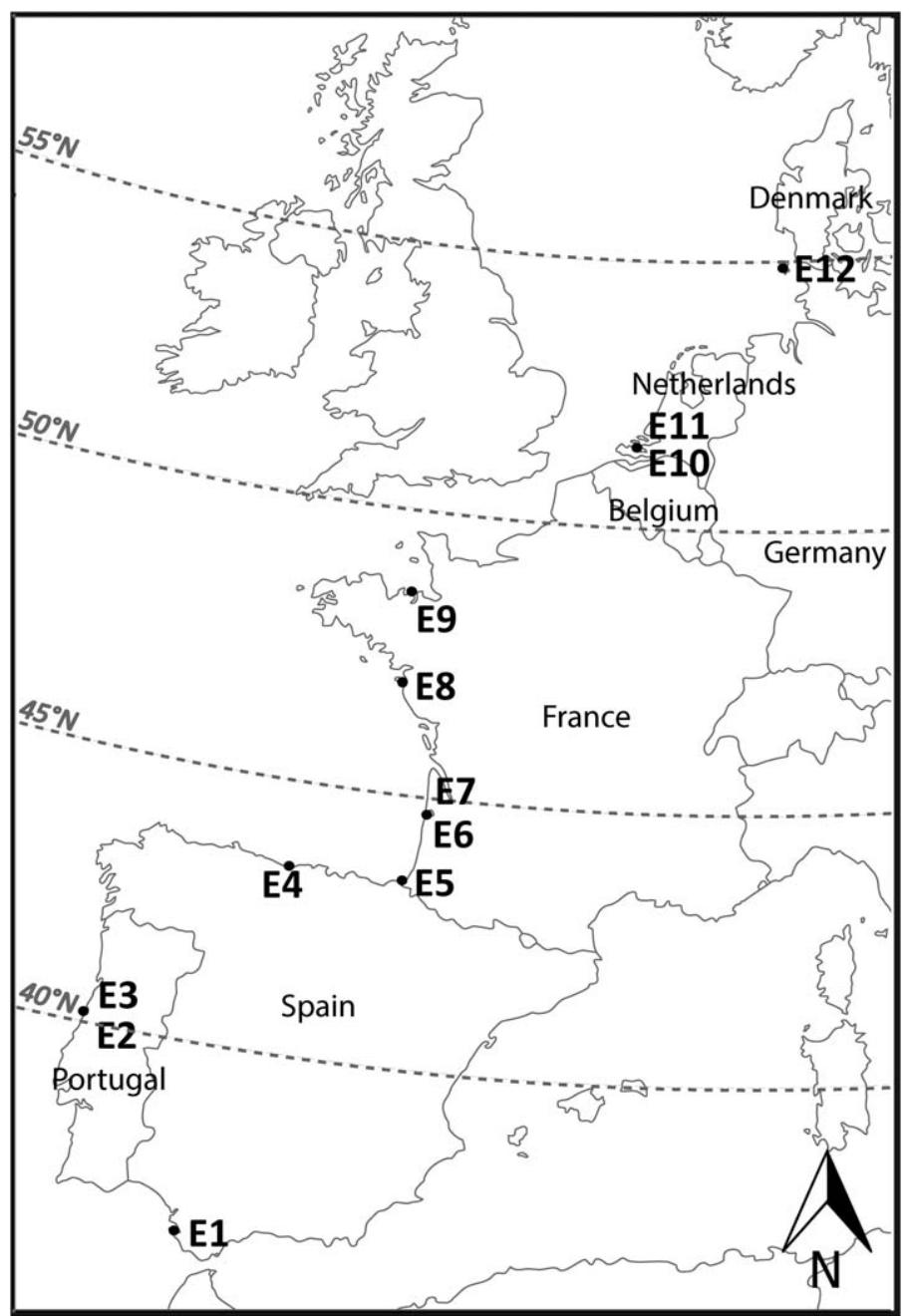

Fig. 1. Studied sites along the Western-European latitudinal gradient.

seagrass meadows). Sampling dates were not identical between meadows since the growth and the length of the growing season are dependent on local conditions such as temperature, light availability, and latitude (Table 1). Water temperature was monitored over the study period at all sites using HOBO Pendant Temperature loggers (64k-UA-002-64, ONSET) at a frequency of one measurement every $30 \mathrm{~min}$. Two loggers were placed within the study area and the temperatures averaged over 1 month around the sampling date for each site (Table 1).

For each sampling date at all sites, five cores were collected at different locations within the seagrass meadow by using a $10 \mathrm{~cm}$ diameter PVC core, inserted into the sediment. Each core contained several seagrass shoots and the distance to collect the cores was far enough to ensure no direct clonal or rhizome connection between replicates. Samples were labeled, carefully washed a first time on site, stored into wet tissues and shipped via express shipment $(<24 \mathrm{~h})$

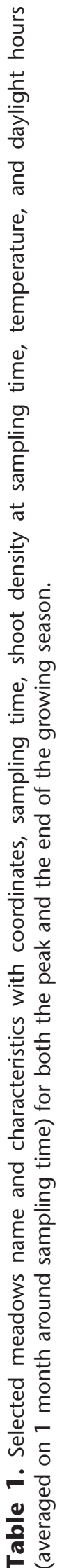

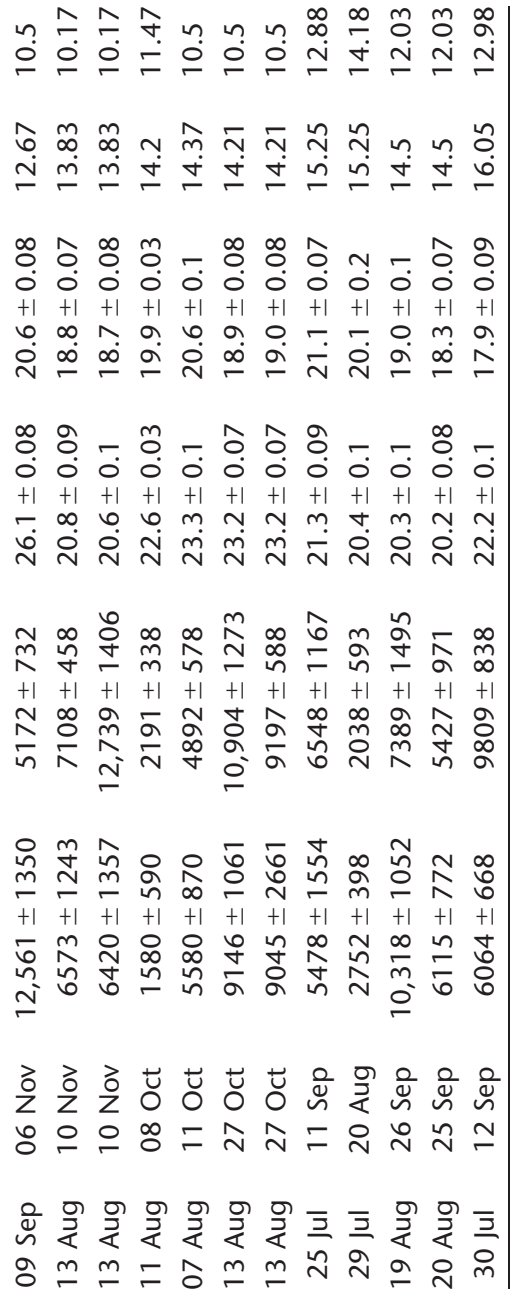

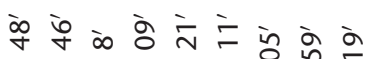

䒕

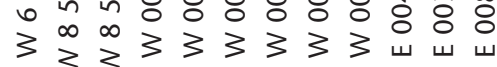

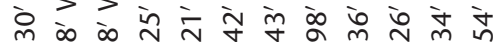

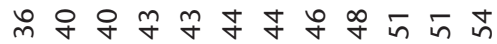
z z z z z z z z z z z z

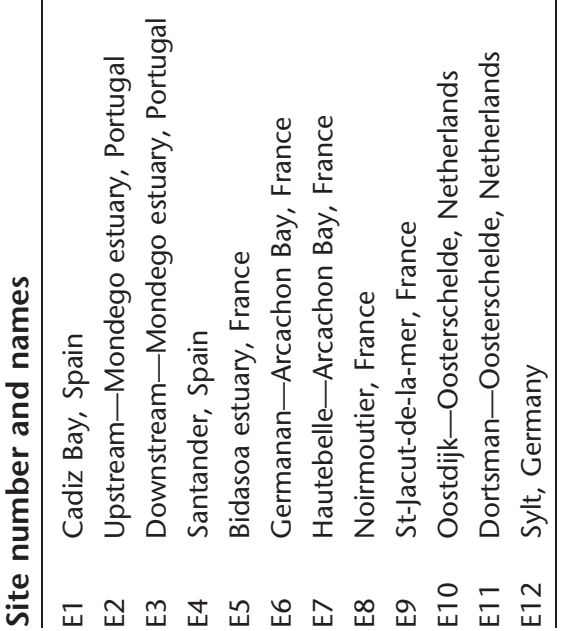


Table 2. List of leaf characteristics measured and calculated with relative units.

\begin{tabular}{llll}
\hline Leaf characteristics & \multicolumn{1}{c}{ Name } & Measure/formula & Units \\
\hline Morphological traits & Length & $L_{0}$ & $L_{\mathrm{W}}$ \\
& Width & $L_{\mathrm{T}}$ & $\mathrm{mm}$ \\
& Thickness & $\mathrm{CA}=L_{\mathrm{W}} \times L_{\mathrm{T}}$ & \\
Mechanical traits & Cross-sectional area & $\mathrm{mm}_{\mathrm{TA}}$ & $\mathrm{mm}$ \\
$(1)$ Tissue properties & Breaking stress & $\delta_{\mathrm{TA}}$ & $\mathrm{m}$ \\
& Absolute extension & $\delta_{\text {max }}=\left(\delta_{\mathrm{TA}} / L_{0}\right) \times 100$ \\
(2) Material properties & Extensibility & $F_{\mathrm{TS}}=F_{\mathrm{TA}} / \mathrm{CA}$ \\
& Strength & $E_{\mathrm{T}}=\left(L_{0} / \mathrm{CA}\right) \times\left(F_{\mathrm{TA}} / \delta_{\mathrm{TA}}\right)$ \\
\hline
\end{tabular}

for further analysis to the Royal Netherland institute of Sea Research (NIOZ) in Yerseke, The Netherlands.

\section{Seagrass traits measurements}

Upon arrival at the NIOZ and prior to mechanical measurements, the samples were carefully washed and epiphytes removed from the plant material. The total number of shoots was firstly noted for shoot density (Table 1). Then, from each sample, five apical shoots were randomly selected for trait analysis. The third leaf from each apical shoot was then cut off at the junction between the sheath and the blade and placed into seawater at room temperature. The rest of the apical shoot was kept and split between aboveground (leaves) and below-ground parts (roots and rhizomes) for further tissue analyses.

\section{Morphological traits}

Morphological traits (Table 2) such as leaf length $\left(L_{0}\right.$, $\mathrm{mm})$, width $\left(L_{\mathrm{W}}, \mathrm{mm}\right)$, and thickness $\left(L_{\mathrm{T}}, \mathrm{mm}\right)$ were measured by using a calliper and dial thickness gauge (Mitutoyo $^{\circledR}$, precision $\left.\pm 0.01 \mathrm{~mm}\right)$. They were used to calculate the cross-sectional area $\left(\mathrm{CA}, \mathrm{mm}^{2}\right)$ (Table 2$)$.

\section{Mechanical traits}

Measures of mechanical traits of the leaves in tension were conducted by using a tensometer (custom made electric actuator with a rated capacity of $5 \mathrm{kN}$ and an accuracy of $0.01 \mathrm{~mm}$ of displacement; Instron ${ }^{\circledR}$ universal testing machine) and the Bluehill software (version 3.0). The tensile tests were performed using a load cell of $10 \mathrm{~N}$ with pneumatic action grips of $5 \mathrm{~N}$ (model 2712). The leaf fragments were individually clamped between the action grips, parallel to the main axis with the mounting $10 \mathrm{~mm}$ apart. During the test, the leaf fragments were stretched at a constant velocity of $10 \mathrm{~mm} \mathrm{~min}{ }^{-1}$. The extension and the load were recorded every $0.1 \mathrm{~s}$ until breakage, where the maximum load $\left(F_{\mathrm{TA}}, \mathrm{N}\right)$ and extension $\left(\delta_{\mathrm{TA}}, \mathrm{mm}\right)$ were recorded. These two direct measurements of tissue properties were defined as (1) the breaking stress $\left(F_{\mathrm{TA}}, \mathrm{N}\right)$, the maximum force each individual fragment can bear before breakage; and (2) the absolute extension $\left(\delta_{\mathrm{TA}}, \mathrm{mm}\right)$, the maximum extension of the fragment before breakage (Table 2 ).

From the recorded measurements and the morphological traits of each leaf fragment, three additional mechanical traits were calculated (Table 2$)$ : (3) the extensibility $\left(\delta_{\max }, \%\right)$ corresponding to the increase in length $\left(\delta_{\mathrm{TA}}\right)$ from the original specimen length $\left(L_{0}\right)$ that occurs before it breaks; $(4)$ the tensile strength $\left(F_{\mathrm{TS}}, \mathrm{N} \mathrm{mm}{ }^{-2}\right)$ which is the maximum force per unit of CA needed to break the leaf fragment; and (5) the stiffness, given by the Young's modulus of elasticity in tension

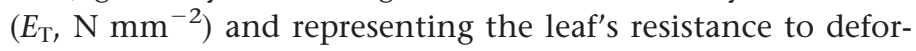
mation (the higher the $E_{\mathrm{T}}$, the stiffer the leaf fragment).

Mechanical traits used in this study were separated into two categories describing (1) the tissue properties, relative to the absolute mechanical property of the leaf fragment (i.e., breaking stress, absolute extension and extensibility); and (2) the material properties, a standardized mechanical property accounting for the leaf morphological traits (i.e., strength, stiffness) (Table 2).

\section{Physiological traits}

Physiological traits were determined by considering the $\mathrm{C}$ : N-ratio in leaf tissues. To measure the $\mathrm{C}: \mathrm{N}$-ratio in leaves, total carbon and nitrogen content were measured on freeze-dried and ground leaf samples using an Elemental Analyzer (EA) Flash 1112, Thermo Scientific. Lyophilized and ground samples were combusted at $1020^{\circ} \mathrm{C}$ in oxic conditions. The nitrous oxides were reduced to $\mathrm{N}_{2}$ with elementary copper at $650^{\circ} \mathrm{C}$ and water was removed by trapping. After separation on a Haysep Q column, $\mathrm{CO}_{2}$ and $\mathrm{N}_{2}$ were detected on a Thermal Conductivity Detector (TCD) detector. The $\mathrm{C}$ : N-ratio was thus calculated by diving the total carbon content by the total nitrogen content obtained.

\section{Statistical analysis}

The latitudinal and seasonal variation (hypothesis 1 and 2) of leaves' morphological (leaf length $L_{0}$, leaf width $L_{\mathrm{w}}$, $\mathrm{CA})$ as well as tissue $\left(F_{\mathrm{TA}}\right.$ and $\left.\delta_{\max }\right)$ and material $\left(F_{\mathrm{TS}}\right.$ and $\left.E_{\mathrm{T}}\right)$ 
Table 3. Results $(F$ and $p$ ) from the mixed effect model testing the seasonal (timing) and latitudinal (latitude) variations morphological, physiological, and mechanical traits of the seagrass meadows studied, as well as the effect of $\mathrm{C}$ : N-ratio as a co-variable.

\begin{tabular}{|c|c|c|c|c|c|c|c|}
\hline & & \multicolumn{2}{|c|}{ Latitude } & \multicolumn{2}{|c|}{ Timing } & \multicolumn{2}{|c|}{$\begin{array}{c}\text { C : N-ratio } \\
\text { (co-variable) }\end{array}$} \\
\hline & & $F$ & $p$ & $F$ & $p$ & $F$ & $p$ \\
\hline \multirow[t]{3}{*}{ Morphological traits } & Leaf length (mm) & 7.796 & $<0.001^{*}$ & 2.706 & 0.101 & 0.441 & 0.507 \\
\hline & Leaf width (mm) & 65.075 & $<0.001^{*}$ & 77.301 & $<0.001^{*}$ & 0.059 & 0.807 \\
\hline & CA $\left(\mathbf{m m}^{2}\right)$ & 52.242 & $<0.001^{*}$ & 37.755 & $<0.001^{*}$ & 1.619 & 0.204 \\
\hline \multirow[t]{3}{*}{ Tissue properties } & Breaking stress $(\mathbf{N})$ & 44.527 & $<0.001^{*}$ & 27.19 & $<0.001^{*}$ & 14.621 & $<0.001^{*}$ \\
\hline & Elongation (mm) & 4.752 & $<0.001^{*}$ & 4.117 & $0.043^{*}$ & 0.081 & 0.776 \\
\hline & Extensibility (\%) & 2.015 & $0.025^{*}$ & 2.395 & 0.122 & 0.048 & 0.826 \\
\hline \multirow[t]{2}{*}{ Material properties } & Strength $\left(\mathrm{N} \mathrm{mm}^{-\mathbf{2}}\right)$ & 7.425 & $<0.001^{*}$ & 0.013 & 0.909 & 7.537 & $0.006^{*}$ \\
\hline & Stiffness $\left(\mathbf{N} \mathbf{~ m m}^{-2}\right)$ & 3.629 & $<0.001^{*}$ & 5.579 & $0.019^{*}$ & 7.311 & $0.007^{*}$ \\
\hline
\end{tabular}

properties across a latitudinal gradient were evaluated with a mixed effect model accounting for the effect of latitude (random factor), season (fixed factor), and C : N-ratio (co-variable). This model will allow to disentangle the effect of nutrient status expressed by physiological traits (hypothesis 3) from the latitudinal and seasonal effects. The seasonal and latitudinal variation of leaf $\mathrm{C}$ : N-ratio was also evaluated with a mixed effect model only accounting for the effect of latitude (random factor) and season (fixed factor). Moreover, a stepwise regression was used to test the relative influence of morphological traits (CA, leaf width $L_{\mathrm{w}}$ ) (hypothesis 4), physiological traits (C : N-ratio) and tissue properties $\left(F_{\mathrm{TA}}, \delta_{\text {max }}\right)$ on material properties $\left(F_{\mathrm{TS}}\right)$. For all tests, data was robust to assumptions, including analysis of data normality and equality of variances. All statistical analyses were performed with R version 3.1.3 (2015-03-09).

\section{Results}

Seasonal variation of leaves characteristics across a

European gradient

\section{Morphological traits}

Leaf width $\left(L_{\mathrm{w}}\right)$ as well as seagrass CA $\left(\mathrm{mm}^{2}\right.$; representing leaf width $\times$ leaf thickness) (Table 3; Fig. 2a) decreased between the peak and the end of the growing season; while leaf length, $\left(L_{0}, \mathrm{~mm}\right)$ did not show any significant changes along the growing season (Table 3 ; Fig. $2 \mathrm{~b}$ ). $L_{0}, L_{\mathrm{w}}$, and CA generally decreased with increasing latitude, with however still high values in the mid-latitudes, particularly at the end of the season for CA (Table 3; Fig. 2a,b).

\section{Tissue properties (absolute mechanical traits)}

Breaking stress $(\mathrm{N})$ presented significantly lower values at the end of the season when compared to the peak of growth (Table 3; Fig. 2c); whereas leaf extensibility (\%) did not significantly differ between the peak and end of the season (Fig. 2d; Table 3).
Both traits, however, significantly decreased along the latitudinal gradient from south to north (Fig. 2c,d; Table 3).

\section{Material properties (standardized mechanical traits)}

Standardized mechanical traits were calculated from absolute mechanical measurements as a function of leaf morphology $\left(L_{0}, C A\right)$. Hence they define the material properties. The leaf strength $\left(\mathrm{N} \mathrm{mm} \mathrm{mm}^{-2}\right)$, as well as the stiffness $(\mathrm{N}$ $\mathrm{mm}^{-2}$ ), were generally lower in northern locations (Table 3; Fig. $2 \mathrm{e}, \mathrm{f})$, meaning that the plants from northern sites were less stiff and easier to break than in the south. Leaf strength significantly decreased of about 1.5-fold from south to north, but not along the growing season (Table 3 ; Fig. 2e). In contrast, leaf stiffness significantly increased along the growing season, particularly in northern sites (Table 3; Fig. 2f).

\section{Physiological traits (C: $\mathrm{N}$-ratio)}

Leaf $\mathrm{C}$ : N-ratio showed a decreasing pattern with increasing latitude during the peak season. This pattern was however not observed at the end of the season, where leaf $\mathrm{C}: \mathrm{N}$ ratio decreased, particularly at the southern locations (Table 3; Fig. 2g).

The influence of morphological and physiological traits on leaves mechanical traits

Besides the effect of the latitudinal gradient and timing on mechanical traits (Table 3), leaf physiological traits (C : N-ratio) co-varied with some tissue and material properties. Sites with high $\mathrm{C}: \mathrm{N}$-ratios showed significantly higher breaking stress $\left(F_{\mathrm{TA}}, \mathrm{N}\right)$, tensile strength $\left(F_{\mathrm{TS}}, \mathrm{N} \mathrm{m}^{-2}\right)$, and stiffness $\left(E_{\mathrm{T}}, \mathrm{N} \mathrm{m}^{-2}\right)$ (Table 3$)$. C : N-ratio had however no significant influence on morphological traits as well as leaf elongation and extensibility (Table 3 ).

A positive linear relationship was observed between CA and breaking stress (Fig. 3) showing the influence of leaves morphological traits on their tissue properties. Furthermore, results from the stepwise regression (including $F_{\mathrm{TA}}, \delta_{\max }$, 
Peak

(a)
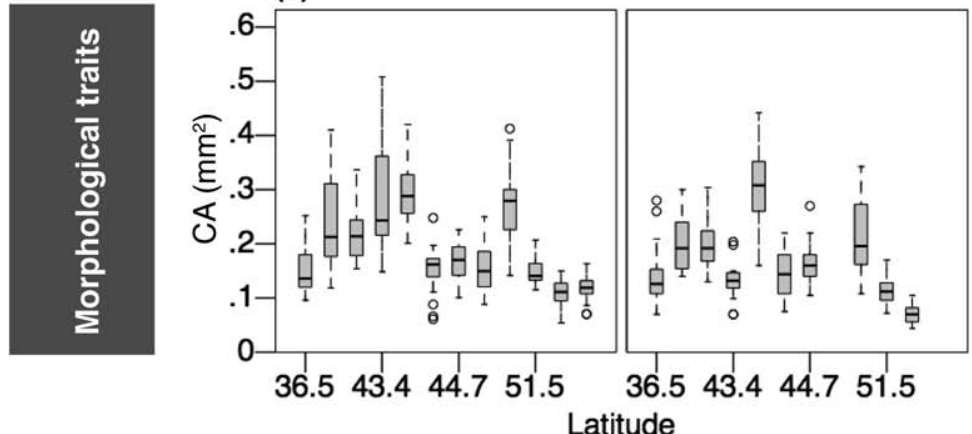

(c)
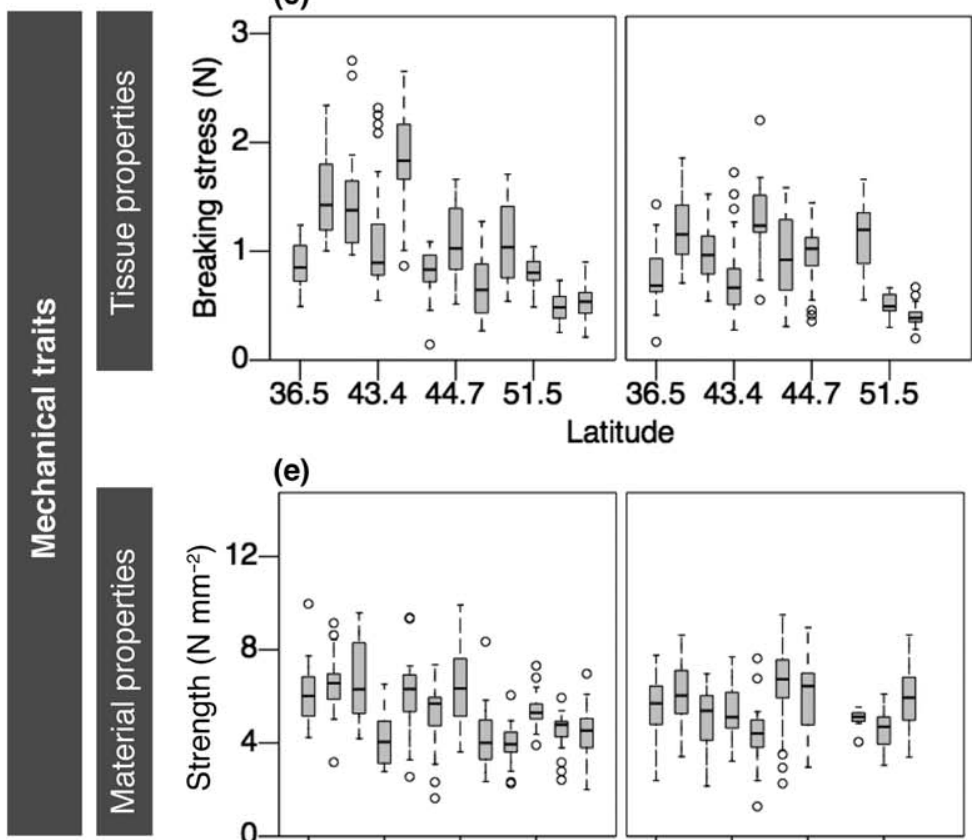

(e)

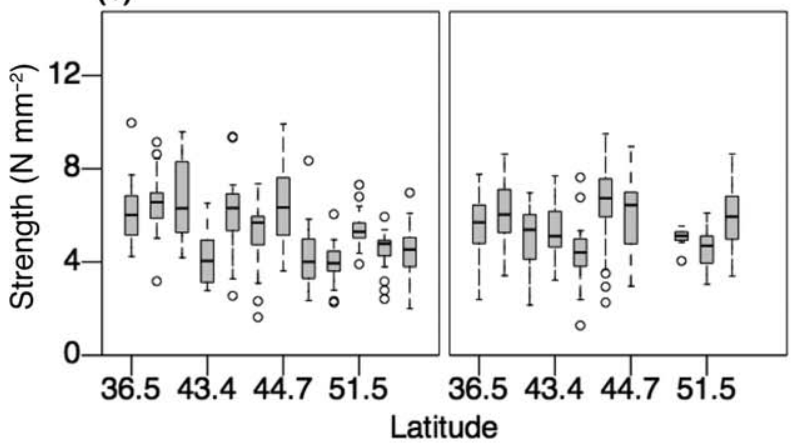

(g)
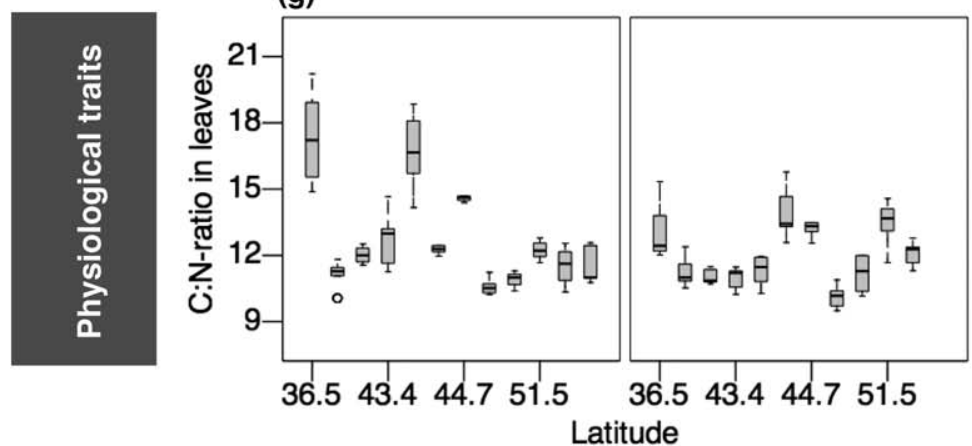

End

Peak

(b)

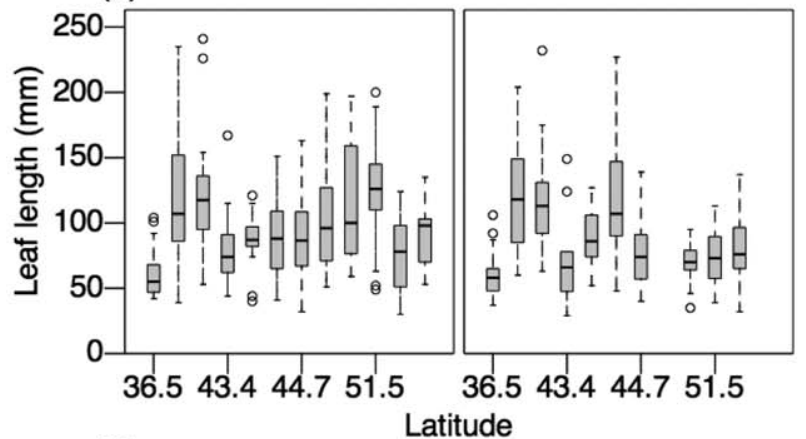

(d)

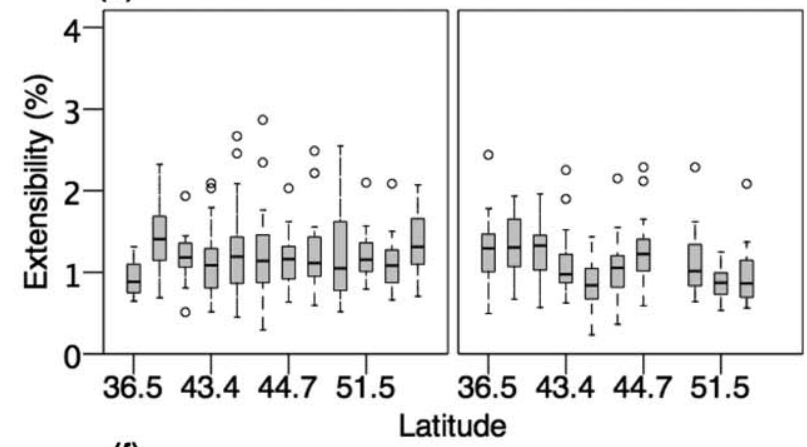

(f)

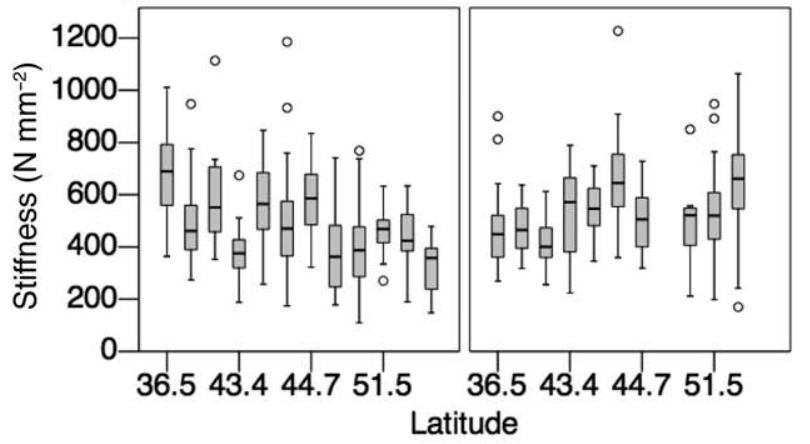

Fig. 2. Box plots representing leaves morphological (a and b), mechanical (c-f), and physiological (g) traits along the latitudinal gradient at the peak and end of their growing season. Mechanical traits are divided between tissue properties (c $\mathbf{c}$ and $\mathbf{d}$; integrated measure relative to the specimen dimensions) and material properties (e and $\mathbf{f}$; standardized measure). 


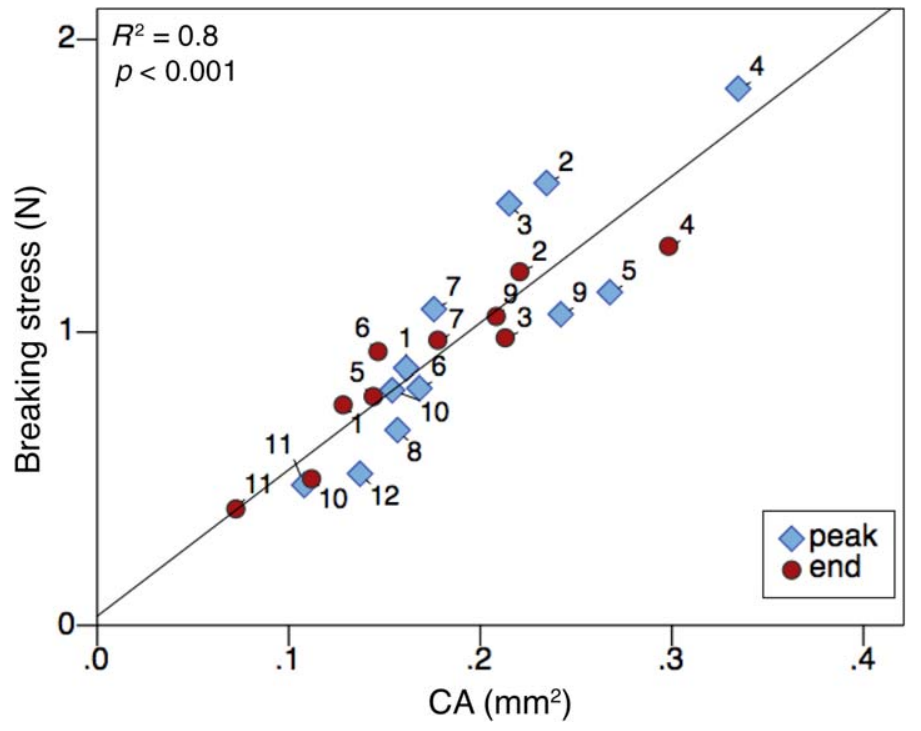

Fig. 3. Linear regression between breaking stress ( $F_{T_{A}} ;$ tissue properties) and CA (morphological trait). Data represent all sites at both the peak and the end of the growing season. Numbers refer to the different sites along the Western-European latitudinal gradient (from South: $1=\mathrm{E} 1$ to North $12=\mathrm{E} 12$ ). [Color figure can be viewed at wileyonlinelibrary.com]

C : N-ratio, CA, and $L_{\mathrm{w}}$ ) showed that the observed variance in leaf strength $\left(F_{\mathrm{TS}}\right)$ was better explained by the combination of leaf breaking stress $\left(F_{\mathrm{TA}}\right), \mathrm{CA}$, and leaf width (total $\left.R^{2}=0.83, p<0.001\right)$. The stepwise regression for $F_{\mathrm{TS}}$ showed that changes in the tissue property $F_{\mathrm{TA}}$ accounted for $20 \%$ of the variance, CA for the next $62 \%$, and $L_{\mathrm{w}}$ for $0.3 \%$; excluding leaf $\mathrm{C}: \mathrm{N}$-ratio and $\delta_{\max }$ from the model.

\section{Discussion}

Seagrasses are sessile organisms able to acclimate their physiological and morphological traits to face the stresses and disturbances they are submitted to (Short and WyllieEcheverria 1996). Plant mechanical traits are important to confer protection and resistance to leaves against currents, waves, or herbivory (Read and Stokes 2006; Onoda et al. 2011). However, these traits remain scarcely understood for seagrasses (La Nafie et al. 2012, 2013; de los Santos et al. 2013). This study reveals that seagrasses have the capacity to acclimate their mechanical traits in relation to their physiological or morphological traits, both over the growing season and across a latitudinal range: leaves are weaker and thinner with increasing latitude, and this effect is more evident at the peak of the growing season. Moreover, we showed that, in addition to the influence of a latitudinal gradient and morphometric plasticity, leaf mechanical traits are also influenced by the leaf nutrient status (i.e., C : N-ratio). In our study, leaves were stronger and stiffer under oligotrophic conditions (high $\mathrm{C}: \mathrm{N}$-ratio) as compared to more eutrophic conditions (low C : N-ratio).

\section{Seagrass mechanical traits along a seasonal and} latitudinal gradient

Along the European coastline, our study showed that seagrass meadows ( $Z$. noltei) have mechanically weaker leaves with a lower $\mathrm{C}$ : N-ratio when latitude increases from south to north, though variation is large (Fig. 2). This variation suggests that seagrass traits could be also affected by other driving variables such as seasonal dynamics (Pérez-Lloréns and Niell 1993; Auby and Labourg 1996; Vermaat and Verhagen 1996; Hansen and Reidenbach 2013) or acclimation to local environmental conditions (Peralta et al. 2005; de los Santos et al. 2013) not driven by the latitudinal gradient.

Most mechanical traits decreased at the end of the growing season, particularly those related to tissue properties such as breaking stress $\left(F_{\mathrm{TA}}\right)$, i.e., the specific force needed to break a leaf. This was particularly the case in northern latitudes, where leaves got thinner (i.e., reduced CA due to reduced leaf width and thickness) before wintering offering less resistance to breakage. Indeed, in northern latitudes, intertidal seagrass populations are usually annual: only the below-ground biomass with limited leaf cover (mostly one leaf left per shoot) remain for the winter period (Hemminga and Duarte 2000; Larkum et al. 2006). At high/northern latitudes where light and temperature get very low during winter, a reduction of leaf width and thickness (i.e., reduced CA) at the end of the season may favor leaf breakage as the strategy for the population to resist these hard conditions. In contrast, at low/southern latitudes where light and temperature decrease mildly in winter, higher leaf width and thickness preserve stronger leaves (see the strong correlation between leaf CA and breaking stress, Fig. 3), allowing the southern seagrass populations to keep growing on a mild winter environment.

\section{Changes in seagrass mechanical traits depending on their nutrient status}

The relationship between eutrophication (C : N-ratio) and mechanical (leaf strength and breaking stress) traits demonstrates the high relevance of local environmental status on seagrass mechanical traits. Under oligotrophic conditions, seagrass meadows typically develop leaves with high $\mathrm{C}: \mathrm{N}$ ratios (Duarte 1990). The present work demonstrates that leaves with high $\mathrm{C}$ : N-ratios are stronger and stiffer than seagrass meadows with a lower $\mathrm{C}$ : N-ratios. Although these mechanical response could be also due to differences in the plant morphotype (i.e., Fig. 3) or growth rate (Peralta et al. 2000), the effect of leaf nutrient status on mechanical traits has been previously observed on terrestrial plants, showing also stronger leaves under low nutrient conditions (Onoda et al. 2008). Our results are also supported by previous findings in the laboratory and on tropical seagrasses (La Nafie et al. 2012, 2013), in which case high nutrients levels (i.e., low C : N-ratio) were correlated to reduced leaf strength and stiffness. 
As seen in our study, seagrass mechanical traits were related to their distribution along a latitudinal gradient, their morphological traits as well as their nutrient status. This overlap suggests that, within a latitudinal gradient, seagrasses have the capacity to adapt to their local high or low nutrient status (as shown by local changes in tissue $\mathrm{C}: \mathrm{N}$ ), helping to withstand more "extreme" nutrient variations (Puijalon et al. 2008; de los Santos et al. 2013; Kohlmeier et al. 2014). Therefore, as observed for other seagrass species (Cymodocea nodosa) under different hydrodynamic conditions (de los Santos et al. 2013), it could be hypothesized that $Z$. noltei's leaves present a plasticity in their mechanical traits that could be modulated by local nutrient status. However, more manipulative work is needed to further understand the consequences of these interactions (i.e., between physiological and mechanical traits) for population resilience.

\section{The influence of morphological traits on tissue and material properties}

The morphometric plasticity and acclimation of seagrasses to local conditions is an efficient mechanism to modulate the plant structural resistance and face the local stresses and disturbances they undergo (Peralta et al. 2005). In a comparative study of over one third of world seagrass species, de los Santos et al. (2016) showed how mechanical traits varied in seagrass species depending on their geographical region (tropical vs. temperate) and their morphological traits, particularly leaf width. Our results support this relationship by showing a strong positive relationship between leaf CA and their tissue properties, expressed as breaking stress. In terrestrial plants, higher leaf mass has been previously associated to higher plant structural resistance and longer lifespan, suggesting that leaf mass is positively related to mechanical resistance (Read and Stokes 2006). Our results also show that wider and thicker leaves (with higher CA) observed in southern seagrass populations from oligotrophic sites presented also stronger tissues, confirming not only previous observations in terrestrial plants (Read and Stokes 2006), but also in other seagrass species (de los Santos et al. 2016).

\section{Implications for the resilience of temperate seagrass meadows}

Overall, our study reports an important aspect of seagrass ecology by showing how they acclimate their mechanical traits along a latitudinal gradient. In northern areas, with darker and cooler winters than in southern areas, seagrass leaves are weaker at the end of the growing season, favoring the loss of photosynthetic tissues for wintering. Moreover, we showed that leaf mechanical traits relate not only to morphological (leaf width and CA), but also to physiological traits (leaf C : N-ratio), showing under oligotrophic conditions stronger and stiffer leaves than under eutrophic ones. The relationships between leaf physiological and mechanical traits are important to evaluate potential effects of eutrophication on seagrass meadows. La Nafie et al. (2012, 2013) also demonstrated that seagrass leaf mechanical traits could be reduced under stressful nutrient enrichment levels, i.e., eutrophic conditions (leaves are easier to break despite their slightly higher extensibility, La Nafie et al. 2013). This means that further eutrophication may affect the strength of seagrass leaves, reducing subsequently the resistance to other stressors such as waves, currents, or herbivory (Read and Stokes 2006; Puijalon et al. 2008, 2011; Onoda et al. 2011). Therefore, understanding the latitudinal consequences of eutrophication is highly important in a context of increasing human activities and threats on coastal areas and climate change.

\section{References}

Auby, I., and P.-J. Labourg. 1996. Seasonal dynamics of Zostera noltii hornem. In the bay of arcachon (France). J. Sea Res. 35: 269-277. doi:10.1016/S1385-1101(96)90754-6

Cabaço, S., R. Machás, and R. Santos. 2009. Individual and population plasticity of the seagrass Zostera noltii along a vertical intertidal gradient. Estuar. Coast. Shelf Sci. 82: 301-308. doi:10.1016/j.ecss.2009.01.020

de Boer, W. F. 2007. Seagrass-sediment interactions, positive feedbacks and critical thresholds for occurrence: A review. Hydrobiologia 591: 5-24. doi:10.1007/s10750-007-0780-9

de los Santos, C. B., F. G. Brun, T. J. Bouma, J. J. Vergara, and J. L. Pérez-Lloréns. 2010. Acclimation of seagrass Zostera noltii to co-occurring hydrodynamic and light stresses. Mar. Ecol. Prog. Ser. 398: 127-135. doi:10.3354/ meps08343

de los Santos, C. B., F. G. Brun, J. J. Vergara, and J. L. PérezLloréns. 2013. New aspect in seagrass acclimation: Leaf mechanical properties vary spatially and seasonally in the temperate species Cymodocea nodosa Ucria (Ascherson). Mar. Biol. 160: 1083-1093. doi:10.1007/s00227-012-2159-3

de los Santos, C. B., Y. Onoda, J. J. Vergara, J. L. PérezLloréns, T. J. Bouma, Y. A. La Nafie, M. L. Cambridge, and F. G. Brun. 2016. A comprenhensive analysis of mechanical and morphological traits in one third of world seagrass species. Mar. Ecol. Prog. Ser. 551: 1-32. doi:10.3354/ meps 11717

Demes, K. W., C. D. G. Harley, L. M. Anderson, and E. Carrington. 2013. Shifts in morphological and mechanical traits compensate for performance costs of reproduction in a wave-swept seaweed. J. Ecol. 101: 963-970. doi: $10.1111 / 1365-2745.12099$

Duarte, C. 1990. Seagrass nutrient content. Mar. Ecol. Prog. Ser. 67: 201-207. doi:10.3354/meps067201

Duarte, C. M. 1991. Seagrass depth limits. Aquat. Bot. 40: 363-377. doi:10.1016/0304-3770(91)90081-F

Duarte, C. M. 2014. Global change and the future ocean: A grand challenge for marine sciences. Front. Mar. Sci. 1: 1-16. doi:10.3389/fmars.2014.00063 
Eriksson, B. K., T. van der Heide, J. van de Koppel, T. Piersma, H. W. Veer, and H. Olff. 2010. Major changes in the ecology of the Wadden Sea: Human impacts, ecosystem engineering and sediment dynamics. Ecosystems 13: 752-764. doi:10.1007/s10021-010-9352-3

Grice, A. M., N. R. Loneragan, and W. C. Dennison. 1996. Light intensity and the interactions between physiology, morphology and stable isotope ratios in five species of seagrass. J. Exp. Mar. Biol. Ecol. 195: 91-110. doi: 10.1016/0022-0981(95)00096-8

Halpern, B. S., and others. 2008. A global map of human impact on marine ecosystems. Science 319: 948-952. doi: 10.1126/science. 1149345

Hansen, J. C. R., and M. A. Reidenbach. 2013. Seasonal growth and senescence of a Zostera marina seagrass meadow alters wave-dominated flow and sediment suspension within a coastal bay. Estuaries Coast. 36: 10991114. doi:10.1007/s12237-013-9620-5

Harder, D. L., C. L. Hurd, and T. Speck. 2006. Comparison of mechanical properties of four large, wave-exposed seaweeds. Am. J. Bot. 93: 1426-1432. doi:10.3732/ ajb.93.10.1426

Hemminga, M. A., and C. M. Duarte. 2000. Seagrass ecology. Cambridge Univ. Press.

Koch, E. W. 2001. Beyond light: Physical, geological, and geochemical parameters as possible submersed aquatic vegetation habitat requirements. Estuaries 24: 1-17. doi: $10.2307 / 1352808$

Kohlmeier, D., C. A. Pilditch, J. F. Bornman, and K. Bischof. 2014. Site specific differences in morphometry and photophysiology in intertidal Zostera muelleri meadows. Aquat. Bot. 116: 104-109. doi:10.1016/j.aquabot.2014.02.011

La Nafie, Y. A., C. B. de los Santos, F. G. Brun, M. M. van Katwijk, and T. J. Bouma. 2012. Waves and high nutrient loads jointly decrease survival and separately affect morphological and biomechanical properties in the seagrass Zostera noltii. Limnol. Oceanogr. 57: 1664-1672. doi: 10.4319/lo.2012.57.6.1664

La Nafie, Y. A., C. B. de los Santos, F. G. Brun, S. Mashoreng, M. M. van Katwijk, and T. J. Bouma. 2013. Biomechanical response of two fast-growing tropical seagrass species subjected to in situ shading and sediment fertilization. J. Exp. Mar. Biol. Ecol. 446: 186-193. doi:10.1016/ j.jembe.2013.05.020

Larkum, A. W. D., R. J. Orth, and C. M. Duarte. 2006. Seagrasses: Biology, ecology and conservation. Springer.

Lee, K.-S., S. R. Park, and Y. K. Kim. 2007. Effects of irradiance, temperature, and nutrients on growth dynamics of seagrasses: A review. J. Exp. Mar. Biol. Ecol. 350: 144-175. doi:10.1016/j.jembe.2007.06.016

Onoda, Y., F. Schieving, and N. P. R. Anten. 2008. Effects of light and nutrient availability on leaf mechanical properties of Plantago major: A conceptual approach. Ann. Bot. 101: 727-736. doi:10.1093/aob/mcn013
Onoda, Y., and others. 2011. Global patterns of leaf mechanical properties. Ecol. Lett. 14: 301-312. doi:10.1111/ j.1461-0248.2010.01582.x

Orth, R. J., and others. 2006. A global crisis for seagrass ecosystems. Bioscience 56: 987-996. doi:10.1641/00063568(2006)56[987:AGCFSE]2.0.CO;2]

Patterson, M. R., M. C. Harwell, L. M. Orth, and R. J. Orth. 2001. Biomechanical properties of the reproductive shoots of eelgrass. Aquat. Bot. 69: 27-40. doi:10.1016/S03043770(00)00133-9

Peralta, G., J. L. Perez-Llorens, I. Hernandez, F. G. Brun, J. Vergara, A. Bartual, and C. M. Garcia. 2000. Morphological and physiological differences between two morphotypes of Zostera noltii Hornem. from the south-western Iberian Peninsula. Helgol. Mar. Res. 54: 80-86. doi: $10.1007 / \mathrm{s} 101520050005$

Peralta, G., J. L. Pérez-Lloréns, I. Hernández, and J. J. Vergara. 2002. Effects of light availability on growth, architecture and nutrient content of the seagrass Zostera noltii Hornem. J. Exp. Mar. Biol. Ecol. 269: 9-26. doi: 10.1016/S0022-0981(01)00393-8

Peralta, G., F. G. Brun, I. Hernández, J. Vergara, and J. Perezllorens. 2005. Morphometric variations as acclimation mechanisms in beds. Estuar. Coast. Shelf Sci. 64: 347-356. doi:10.1016/j.ecss.2005.02.027

Pérez-Lloréns, J. L., and F. X. Niell. 1993. Seasonal dynamics of biomass and nutrient content in the intertidal seagrass Zostera noltii Hornem. from Palmones River estuary, Spain. Aquat. Bot. 46: 49-66. doi:10.1016/03043770(93)90064-4

Puijalon, S., J.-P. Léna, N. Rivière, J.-Y. Champagne, J.-C. Rostan, and G. Bornette. 2008. Phenotypic plasticity in response to mechanical stress: Hydrodynamic performance and fitness of four aquatic plant species. New Phytol. 177: 907-917. doi:10.1111/j.1469-8137.2007.02314.x

Puijalon, S., T. J. Bouma, C. J. Douady, J. Van Groenendael, N. P. R. Anten, E. Martel, and G. Bornette. 2011. Plant resistance to mechanical stress: Evidence of an avoidance - tolerance trade-off. New Phytol. 191: 1141-1149. doi: 10.1111/j.1469-8137.2011.03763.x

Read, J., and A. Stokes. 2006. Plant biomechanics in an ecological context. Am. J. Bot. 93: 1546-1565. doi:10.3732/ ajb.93.10.1546

Roca, G., and others. 2016. Response of seagrass indicators to shifts in environmental stressors: A global review and management synthesis. Ecol. Indic. 63: 310-323. doi: 10.1016/j.ecolind.2015.12.007

Short, F., T. Carruthers, W. Dennison, and M. Waycott. 2007. Global seagrass distribution and diversity: A bioregional model. J. Exp. Mar. Biol. Ecol. 350: 3-20. doi: 10.1016/j.jembe.2007.06.012

Short, F. T., and S. Wyllie-Echeverria. 1996. Natural and human-induced disturbance of seagrasses. Environ. Conserv. 23: 17-27. doi:10.1017/S0376892900038212 
Short, F. T., and H. A. Neckles. 1999. The effects of global climate change on seagrasses. Aquat. Bot. 63: 169-196. doi:10.1016/S0304-3770(98)00117-X

Touchette, B. W., and J. M. Burkholder. 2000. Review of nitrogen and phosphorus metabolism in seagrasses. J. Exp. Mar. Biol. Ecol. 250: 133-167. doi:10.1016/S00220981(00)00195-7

Valle, M., G. Chust, A. del Campo, M. S. Wisz, S. M. Olsen, J. M. Garmendia, and Á. Borja. 2014. Projecting future distribution of the seagrass Zostera noltii under global warming and sea level rise. Biol. Conserv. 170: 74-85. doi:10.1016/j.biocon.2013.12.017

Vermaat, J. E., and F. C. A. Verhagen. 1996. Seasonal variation in the intertidal seagrass Zostera noltii Hornem.: Coupling demographic and physiological patterns. Aquat. Bot. 52: 259-281. doi:10.1016/0304-3770(95)00510-2

Waycott, M., and others. 2009. Accelerating loss of seagrasses across the globe threatens coastal ecosystems. Proc. Natl. Acad. Sci. USA. 106: 12377-12381. doi: 10.1073/pnas.0905620106

Wicks, E. C., E. W. Koch, J. M. O'Neil, and K. Elliston. 2009. Effects of sediment organic content and hydrodynamic conditions on the growth and distribution of Zostera marina. Mar. Ecol. Prog. Ser. 378: 71-80. doi:10.3354/ meps07885

\section{Acknowledgments}

The authors are grateful to all students and volunteers who helped to collect samples during the European sampling study. We also thank Lennart van ljzerloo, Jeroen van Dalen, and Miriam Loth for their assistance in setting up and working with the INSTRON, and Peter van Breugel for his help with laboratory analyses. This research was supported by the Netherlands Organisation for Scientific Research (project No. 843.10.003) as part of the Ph.D. project of Laura Soissons, the first author. The dataset used in this manuscript is available online: 10.4121/ uuid:3f579ba7-48fc-45cc-a273-20eb541b434b.

\section{Conflict of Interest}

None declared.

Submitted 23 August 2016

Revised 15 February 2017

Accepted 16 May 2017

Associate editor: Núria Marbà 